\title{
Electrodeposition of Zn-Ni Alloy from An Alkaline Sulphate Bath Containing Triethanolamine and Mercaptopyridine
}

\author{
V. Narasimhamurthy ${ }^{1, *}$, L.H. Shivashankarappa ${ }^{2}$ \\ ${ }^{1}$ Government First Grade College and Post Graduate Study Center, Shivamogga - 577 201, Karnataka, India. \\ ${ }^{2}$ Maharani Science College for Women, Palace Road, Bengaluru - 560 001, Karnataka, India.
}

\section{ART IC LE DETAILS}

\section{Article history:}

Received 22 September 2020

Accepted 13 October 2020

Available online 26 October 2020

\section{Keywords:}

Triethanolamine

Electrodeposition

Zinc-Nickel Alloy

Cathodic Current Efficiency

\begin{abstract}
A B S T R A C T
Electrodeposition of $\mathrm{Zn}-\mathrm{Ni}$ alloy from non-cyanide alkaline sulphate bath containing triethanolamine (TEA) and mercaptopyridine (MPY) under optimized plating conditions such as bath $\mathrm{pH}$, temperature current density and metal ion ratio in the bath produced an alloy deposit with the desired composition of 10-15 \%wt. of nickel, alloy of this composition showed good adhesion, high hardness pore free, smooth, uniform and finer grained. Deposition potentials of $\mathrm{Zn}-\mathrm{Ni}$ alloy lie between the potentials of individual metals. Increase in temperature density decreased the nickel content in the alloy deposit, which with increase in temperature and thickness of the alloy deposit increased nickel content in the alloy deposit. Alloy deposition followed a regular type of co-deposition.
\end{abstract}

\section{Introduction}

Electrodeposition of Zn-Ni alloys containing 10-15 \%wt. Ni have received greater attention, because these alloys provide improved corrosion resistance to steel than conventional zinc coatings. The zincnickel alloys have been deposited from various types of baths such as sulphate [1,2], chlorides [3,4], sulphamate [5,6], pyrophosphates [7-9], ammonical [10-12] and cyanide [13-16] baths.

Alkaline Zn-Ni alloy system has proved to be functional substituted for zinc and cadmium electrodeposits. Compared to cadmium, alkaline zincnickel alloy system not only offers greater resistance to corrosion but also reduces the health hazards caused involving cadmium since it is toxic. There are only a few reports cited in the literature on the electrodeposition of $\mathrm{Zn}-\mathrm{Ni}$ alloy from an alkaline sulphate baths. The main disadvantages of alkaline sulphate baths is the loss of ammonia at high operating temperature, which makes the process difficult to operate and control the plating conditions. The problems encountered in the effluent treatment of alkaline baths containing cyanide is another limitation. In order to overcome these problems, it was felt to develop a non-cyanide and ammonia free alkaline sulphate bath for the electrodeposition of $\mathrm{Zn}-\mathrm{Ni}$ alloy, which is easy to operate with no effluent problems. Therefore, we tried to develop alkaline sulphate bath containing triethanolamine(TEA) as a complexing agent and mercaptopyridine(MPY) as a brighter for the electrodeposition of $\mathrm{Zn}-\mathrm{Ni}$ alloy. The results obtained are reported in this paper.

\section{Experimental Methods}

The plating bath solutions were prepared by using distilled water and laboratory grade chemicals. The bath solution was purified as described elsewhere. Table 1 lists the bath composition and operating conditions used for plating. Hull cell experiments were carried out in a standard 267 $\mathrm{mL}$ cell for 5 minutes at $1 \mathrm{~A}$ cell current. The test results were utilized to optimize the plating conditions. Electrodeposition was carried out galvonostaticlly at $55^{\circ} \mathrm{C}$ under stirred conditions. The percentage of zinc and nickel content in the alloy deposit was determined by plating on the stainless steel cathode having the area $1 \mathrm{~cm}^{2}$. The panel so plated was weighed, then stripped in 20 per cent $\mathrm{HNO}_{3}$ and made up to $100 \mathrm{~mL}$ in a

*Corresponding Author:drvnm123@gmail.com(V. Narasimhamurthy) standard flask. The zinc and nickel concentrations in the solution were determined by atomic absorption spectrometry.

During plating, deposition potentials were recorded with respect to saturated calomel electrode using scanning potentiostat (model CL-95, Elico, India). The cathodic current efficiencies (CCE), deposition rates were calculated in the conventional manner. The thickness of the alloy deposit was determined by using Elicometer (model 256 FN, UK). The adhesion of $\mathrm{Zn}-\mathrm{Ni}$ alloy deposits to the base metal (steel) was tested by standard bending test. The porosity of alloy deposit was determined by ferroxyl test., micro hardness of the alloy deposits containing various nickel contents were determined on Vickers scale with a $50 \mathrm{~g}$ - load (Zwick 32122, Germany). Scanning electronic microscope (model JEOL-JSM $840 \mathrm{~A}$ ) was used to examine the surface morphology of the alloy deposits coated on a polished copper substrate.

Table 1 Bath composition and operating conditions for electroplating of $\mathrm{Zn}-\mathrm{Ni}$ alloy from an alkaline sulphate bath containing TEA and MPY

\begin{tabular}{lll}
\hline Bath composition & Range studied & $\begin{array}{l}\text { Optimum composition and } \\
\text { conditions }\end{array}$ \\
\hline Total metal content & $0.2 \mathrm{M}$ & $0.2 \mathrm{M}$ \\
$\mathrm{ZnSO}_{4} \cdot 7 \mathrm{H}_{2} \mathrm{O}$ & $0.192-0.198 \mathrm{M}$ & $0.196 \mathrm{M}$ \\
$\mathrm{NiSO}_{4} \cdot 7 \mathrm{H}_{2} \mathrm{O}$ & $0.002-0.008 \mathrm{M}$ & $0.004 \mathrm{M}$ \\
$\mathrm{TEA}$ & $10-60 \mathrm{~mL} / \mathrm{L}$ & $40 \mathrm{~mL} / \mathrm{L}$ \\
$\mathrm{MPY}$ & $0.0025-0.04 \mathrm{M}$ & $0.01 \mathrm{M}$ \\
$\mathrm{Na}_{2} \mathrm{SO}_{4}$ & $20-100 \mathrm{~g} / \mathrm{L}$ & $50 \mathrm{~g} / \mathrm{L}$ \\
$\mathrm{NaOH}$ & $20-160 \mathrm{~g} / \mathrm{L}$ & $100 \mathrm{~g} / \mathrm{L}$ \\
$\mathrm{Saccharin}$ & $1-8 \mathrm{~g} / \mathrm{L}$ & $2 \mathrm{~g} / \mathrm{L}$ \\
pH & - & $>14$ \\
Current density & $5-35 \mathrm{Adm}^{-2}$ & $15 \mathrm{Adm}{ }^{-2}$ \\
Temperature & $25-75^{\circ} \mathrm{C}$ & $55^{\circ} \mathrm{C}$ \\
Agitation & - & Normal \\
\hline
\end{tabular}

\section{Results and Discussion}

\subsection{Effect of Metal Ion Ratio}

In order study the zinc to nickel ratio in the plating bath on alloy composition, zinc to iron ratio in the bath was varied from 96.4 to 99.5 at $55^{\circ} \mathrm{C}$, constant thickness $\sim 4 \mu \mathrm{m}$ for three different current densities $(10$, 20 and $35 \mathrm{~mA} / \mathrm{cm}^{2}$ ). Fig. 1 shows the variation of alloy composition with bath composition. In the graph, the line $\mathrm{AB}$ is the composition reference line (CRL), which represents the zinc to nickel ratio in the bath, which is equal to zinc to nickel ratio in the alloy deposit. A bath solution with less nickel content (12.4 per cent) indicating that more noble metal (nickel) 
depositing preferentially, that is the curves in the graph for the percentage of nickel in the alloy deposit are well above the CRL line AB. This shows that the deposition is of regular type with nickel as the more noble metal.

\subsection{Effect of Current Density}

The effect of current density on alloy composition was studied by carrying out the experiments at various current densities $\left(10-35 \mathrm{~mA} / \mathrm{cm}^{2}\right)$ at $55^{\circ} \mathrm{C}$, thickness $\sim 4 \mu \mathrm{m}, \mathrm{pH}>14$ under stirred conditions. Fig. 2 illustrates the dependency of the alloy composition on current density from the baths containing various zinc to nickel ion ratios (Zn: Ni 97:3, 98:2 and 99:1). With increase in current density, the percentage of nickel in the alloy deposit decreased. At higher current densities (more than $25 \mathrm{~mA} / \mathrm{cm}^{2}$ ), the percentage of nickel in the alloy deposit attained a steady value, this shows a steady rates of discharge of nickel ions at the cathode at higher current densities.

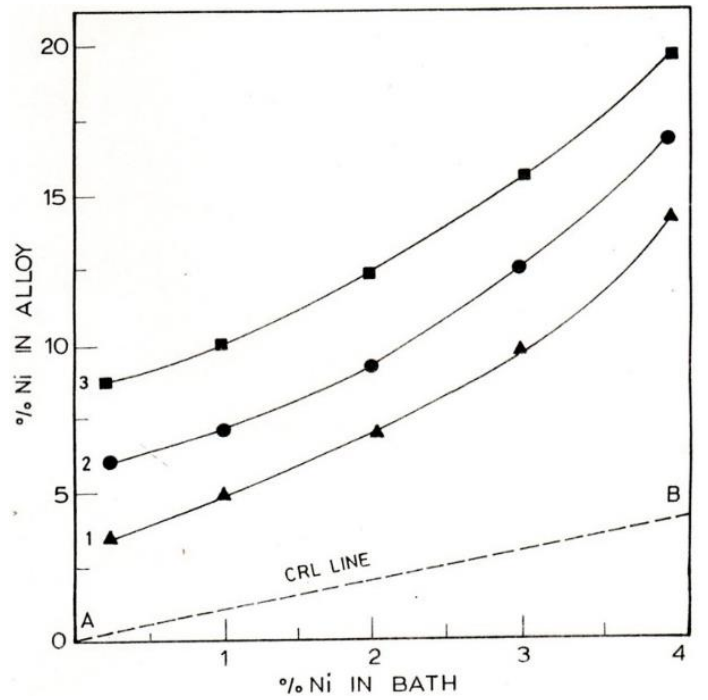

Fig. 1 Dependence of alloy composition on bath composition. Bath composition: Total metal $0.2 \mathrm{M},\left[\mathrm{Zn}^{2+}\right] 0.192$ to $0.198 \mathrm{M},\left[\mathrm{Ni}^{2+}\right] 0.002-0.008 \mathrm{M}$, TEA $40 \mathrm{~mL} / \mathrm{L}, \mathrm{MPY}$ $0.01 \mathrm{M}, \mathrm{Na}_{2} \mathrm{SO}_{4} 50 \mathrm{~g} / \mathrm{L}$, NaOH $100 \mathrm{~g} / \mathrm{L}$, Saccharin $2 \mathrm{~g} / \mathrm{L}$, temperature $55^{\circ} \mathrm{C}$ current density $10-35 \mathrm{~mA} / \mathrm{cm}^{2}$, thickness $\sim 2 \mu \mathrm{m}, \mathrm{pH}>14$, stirred condition. Curve 1: 35 $\mathrm{mA} / \mathrm{cm}^{2}$; Curve $2: 20 \mathrm{~mA} / \mathrm{cm}^{2}$; Curve $3: 10 \mathrm{~mA} / \mathrm{cm}^{2}$

\subsection{Effect of Temperature}

In order to know the effect of temperature on the composition of $\mathrm{Zn}-\mathrm{Ni}$ alloy, experiments were carried out at various temperature $\left(25-75^{\circ} \mathrm{C}\right)$ at $15 \mathrm{~mA} / \mathrm{cm}^{2}$, thickness $\sim 4 \mu \mathrm{m}$ under stirred conditions from the baths containing different zinc to nickel ion ratio. An increase in temperature increases the percentage of nickel (more noble) in the $\mathrm{Zn}-\mathrm{Ni}$ alloy deposit (Table 2). This is because an increase in temperature might increase the preferentially depositing metal (nickel) ion concentration in the cathode diffusion layer, confirming the $\mathrm{Zn}-\mathrm{Ni}$ alloy deposition to be of regular type.

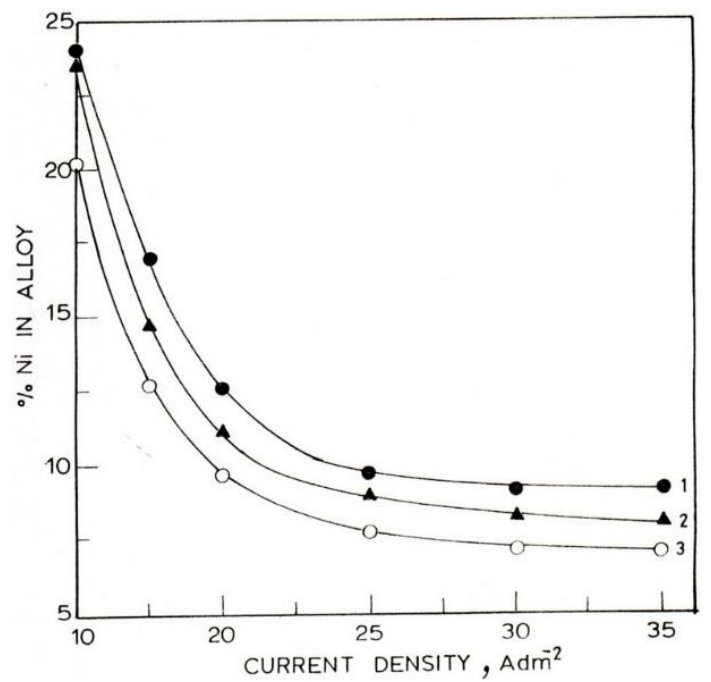

Fig. 2 Variation of alloy composition with current density. Bath composition: Total metal 0.2 M, [ $\left.\mathrm{Zn}^{2+}\right]$ 0.194-0.198 M, [Ni ${ }^{2+}$ 0.002-0.006 M, TEA $40 \mathrm{~mL} / \mathrm{L}, \mathrm{MPY} 0.01 \mathrm{M}$, $\mathrm{Na}_{2} \mathrm{SO}_{4} 50 \mathrm{~g} / \mathrm{L}, \mathrm{NaOH} 100 \mathrm{~g} / \mathrm{L}$, Saccharin $2 \mathrm{~g} / \mathrm{L}$, temperature $55^{\circ} \mathrm{C}$ current density 10-35 mA $/ \mathrm{cm}^{2}$, thickness $\sim 2 \mu \mathrm{m}, \mathrm{pH}>14$, stirred condition. Curve 1: $97: 3 \mathrm{Zn}: \mathrm{Ni}$; Curve 2: 98:2 Zn:Ni; Curve 3: 99:1 Zn:Ni.

https://doi.org/10.30799/jaec.061.20060103
Table 2 Effect of temperature of the operating bath on composition $\mathrm{Zn}$-Ni alloy from an alkaline sulphate bath

\begin{tabular}{llll}
\hline \multirow{2}{*}{ Temperature $\left({ }^{\circ} \mathrm{C}\right)$} & \multicolumn{3}{l}{ \% Ni in Zn-Ni alloy } \\
\cline { 2 - 4 } & $99 / 1 \mathrm{Zn} / \mathrm{Ni}$ & $98 / 2 \mathrm{Zn} / \mathrm{Ni}$ & $97 / 3 \mathrm{Zn} / \mathrm{Ni}$ \\
\hline 25 & 10.03 & 11.92 & 14.54 \\
35 & 12.77 & 13.82 & 16.70 \\
45 & 13.23 & 14.56 & 18.11 \\
55 & 15.06 & 17.66 & 21.01 \\
65 & 17.24 & 22.35 & 24.23 \\
75 & 21.46 & 25.89 & 29.26 \\
Stirring & - & Normal \\
\hline
\end{tabular}

Bath composition: Total metal 0.2 M, [ $\left.\mathrm{Zn}^{2+}\right]$ 0.194-0.198 M, [Co $\left.{ }^{2+}\right] 0.002-006 \mathrm{M}, \mathrm{TEA} 40$ $\mathrm{mL} / \mathrm{L}, \mathrm{MPY} 0.01 \mathrm{M}, \mathrm{Na}_{2} \mathrm{SO}_{4} 50 \mathrm{~g} / \mathrm{L}, \mathrm{NaOH} 100 \mathrm{~g} / \mathrm{L}$, Saccharin $2 \mathrm{~g} / \mathrm{L}$, current density 15 $\mathrm{mA} / \mathrm{cm}^{2}, \mathrm{pH}>14$, thickness $\sim 2 \mu \mathrm{m}$, stirred condition

\subsection{Effect of Triethanolamine (TEA) and Mercaptopyridine (MPY)}

Triethanolamine (TEA) was found to be suitable complexing agent for zinc and nickel, experiments were conducted at $15 \mathrm{~mA} / \mathrm{cm}^{2}, 55^{\circ} \mathrm{C}, \mathrm{pH}>14$, thickness $\sim 4 \mu \mathrm{m}$ from the baths containing various concentrations of TEA and MPY. Fig. 3 shows the dependence of alloy composition with the concentrations of TEA and MPY. An increase in the concentration of TEA, up to $20 \mathrm{~mL} / \mathrm{L}$ decreased the percentage of nickel in the alloy deposit and finally attained a steady value. In the case of MPY, with an increase in its concentration, the percentage of nickel in the alloy deposit increases to a steady value at higher concentration.

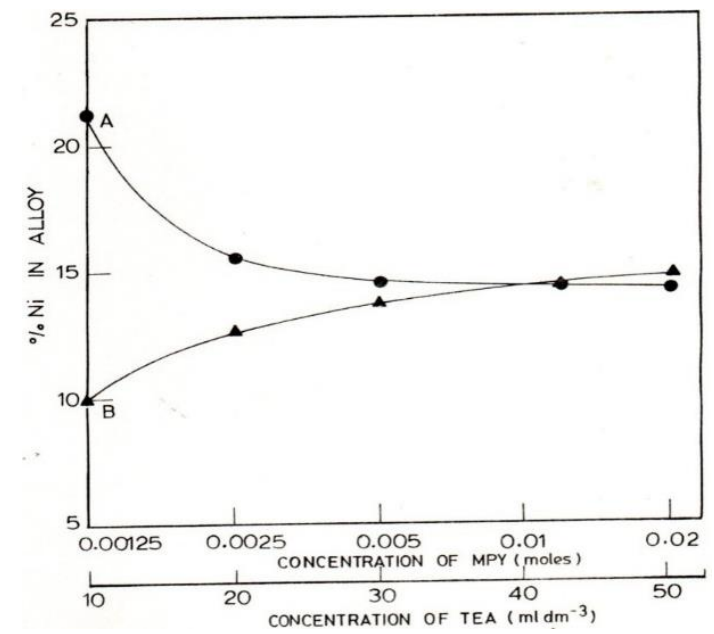

Fig. 3 Variation of the \% of nickel in the $\mathrm{Zn}-\mathrm{Ni}$ alloy deposits with the concentrations of TEA and MPY in the plating bath. Bath composition: Total metal $0.2 \mathrm{M},\left[\mathrm{Zn}^{2+}\right]$ 0.194M, [Ni $\left.{ }^{2+}\right]$ 0.004M, TEA 10-50 mL/L, MPY 0.00625-0.02 M, Na $\mathrm{SO}_{4} 50 \mathrm{~g} / \mathrm{L}, \mathrm{NaOH}$ $100 \mathrm{~g} / \mathrm{L}$, Saccharin $2 \mathrm{~g} / \mathrm{L}$, temperature $55^{\circ} \mathrm{C}$, current density $15 \mathrm{~mA} / \mathrm{cm}^{2}$, thickness $\sim 2 \mu \mathrm{m}, \mathrm{pH}>14$, stirred condition.

\subsection{Effect of Thickness}

The dependence of alloy composition with the deposit thickness is shown in Fig. 4. Increase in the thickness of the alloy deposit increased the percentage of nickel in the alloy deposit.

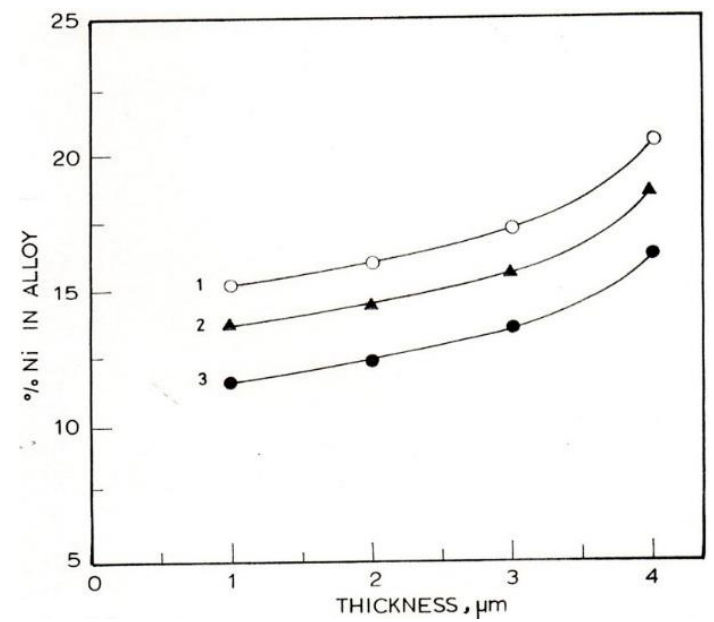

Fig. 4 Dependence of alloy composition on thickness of the alloy deposit. Bath

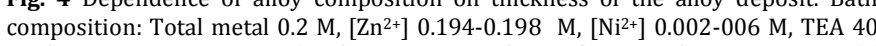
$\mathrm{mL} / \mathrm{L}$, MPY $0.01 \mathrm{M}, \mathrm{Na}_{2} \mathrm{SO}_{4} 50 \mathrm{~g} / \mathrm{L}, \mathrm{NaOH} 100 \mathrm{~g} / \mathrm{L}$, Saccharin $2 \mathrm{~g} / \mathrm{L}$, temperature 55 ${ }^{\circ} \mathrm{C}$ current density $15 \mathrm{~mA} / \mathrm{cm}^{2}$, thickness $\sim 1-4 \mu \mathrm{m}, \mathrm{pH}>14$, stirred condition. Curve 1: 97:3 Zn:Ni; Curve 2: 98:2 Zn:Ni; Curve 3: 99:1 Zn:Ni. 


\subsection{Cathodic Current Efficiency (CCE)}

The cathodic current efficiencies were calculated for $\mathrm{Zn}-\mathrm{Ni}$ alloy deposition under each set of conditions. The dependency of CCE on current density is shown in Fig. 5. With an increase in current density, the CCE was found to decrease, stirring and increase in bath temperature increased the CCE.

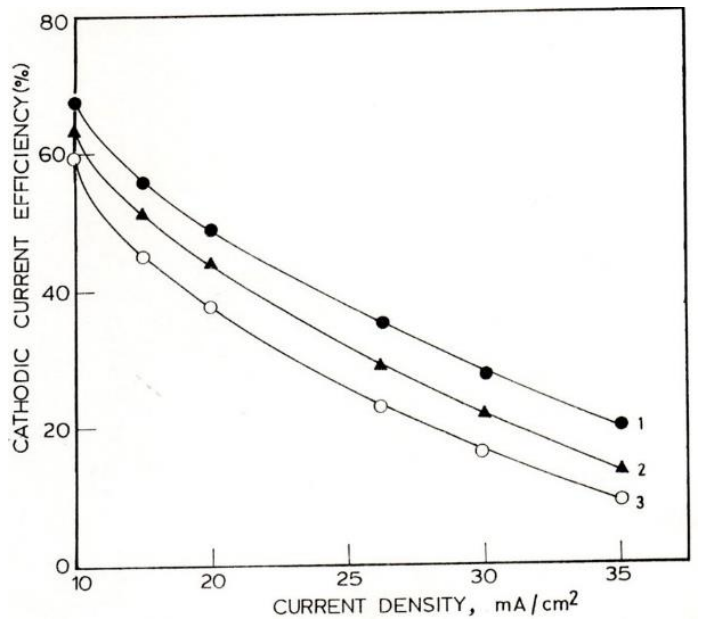

Fig. 5 Dependency of cathodic current efficiency on the current density. Curve 1:97:3 $\mathrm{Zn:Ni}$; Curve 2: 98:2 Zn:Ni; Curve 3: 99:1 Zn:Ni

\subsection{Cathodic Polarization Characteristics}

Fig. 6 shows the polarization characteristics of zinc, nickel and zincnickel alloy deposition. Curve 1 represents the deposition of nickel alone at a potential of about $-0.90 \mathrm{~V}$, curve 2 corresponds to zinc deposition alone, the deposition potential being $-1.55 \mathrm{~V}$ and curve 3 is for $\mathrm{Zn}-\mathrm{Ni}$ alloy deposition. The deposition was intermediate between nickel and zinc ($1.10 \mathrm{~V}$ ) which is less noble to nickel and more noble to zinc. This current density - potential characteristics for Zn-Ni alloy deposition clearly shows the cause for regular type of co-deposition.

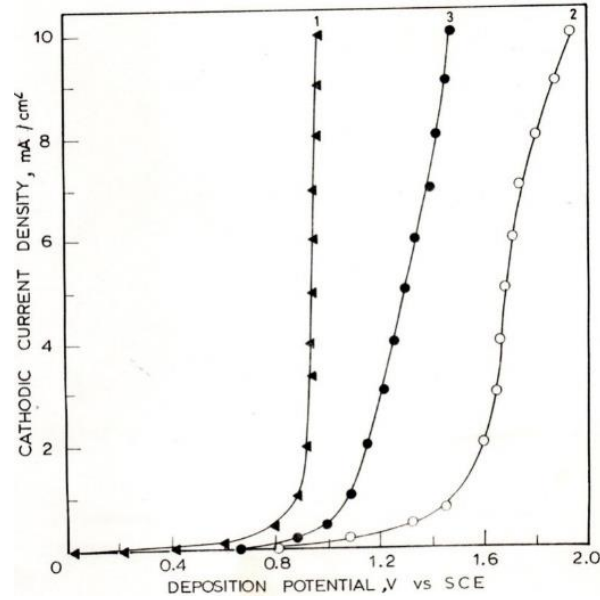

Fig. 6 Cathodic polarization curves for the deposition of zinc, nickel and Zn-Ni. Alloy from on alkaline sulphate bath. All solutions contained triethanolamine $40 \mathrm{~mL} / \mathrm{L}$, mercaptopyridine $0.01 \mathrm{M}, \mathrm{Na}_{2} \mathrm{SO}_{4} 50 \mathrm{~g} / \mathrm{L}$, saccharin $2 \mathrm{~g} / \mathrm{L}$, temperature $55{ }^{\circ} \mathrm{C}$ Stirred condition. Curve 1: deposition of nickel alone, Curve 2: deposition of zinc alone, Curve 3: deposition of zink-nickel alloy. The bath solution contained same concentration of nickel and zinc as those in the individual baths

\subsection{Properties and Morphology}

The adhesion of the Zn-Ni alloy deposit to the base metal (steel) was tested by a standard bending test. Zn-Ni alloy samples coated to different thickness $(2-6 \mu \mathrm{m})$ on steel $(1 \times 4 \mathrm{sq}$. inch) were subjected to bending test. The alloy coating did not develop any visual cracks even after $180^{\circ}$ bending. This shows a good adhesion of the alloy deposit to the base metal.

Porosity tests were conducted on $\mathrm{Zn}-\mathrm{Ni}$ alloy coasted on steel $(3 \times 3$ sq. inch) to a thickness of 2-6 $\mu \mathrm{m}$. A filter paper soaked in $1 \% \mathrm{~K}_{4} \mathrm{Fe}(\mathrm{CN})_{6}$ solution placed on alloy coated steel panels. Appearance of blue spots on the filter paper with time was observed. The number of blue spots appearing on the filter paper with time is a measure of porosity of the deposit. The alloy deposits were pore free at sufficient thickness $(>4 \mu \mathrm{m})$. Microhardness of $6 \mu \mathrm{m}$ thick $\mathrm{Zn}-\mathrm{Ni}$ alloy specimens was determined on
Vickers scale (load-50 g). Hardness of the alloy deposit increased with an increase in the percentage of nickel in $\mathrm{Zn}-\mathrm{Ni}$ alloy deposit (Table 3).

The static potentials of Zinc and Zinc-Nickel alloys were measured in $3.5 \% \mathrm{NaCl}$ solution with respect to SCE. Table 3 lists the static potential values for zinc and $\mathrm{Zn}-\mathrm{Ni}$ alloy. Static potentials of $\mathrm{Zn}-\mathrm{Ni}$ alloys were found to be nobler of zinc indicating corrosion resistant characteristics.

Table 3 Effect of percentage of Nickel on hardness of $\mathrm{Zn}-\mathrm{Ni}$ alloy and static potential values

\begin{tabular}{lll}
\hline \%Ni in Zn-Ni alloy & $\begin{array}{l}\text { Hardness in V.H.N. (load } \\
-50 \mathrm{gm})\end{array}$ & $\begin{array}{l}\text { Static potentials in } \mathrm{mV} \text { Vs SCE } \\
\text { measured in } 3.5 \% \mathrm{NaCl}\end{array}$ \\
\hline 0 & 98 & -1120 \\
5 & 282 & -1070 \\
10 & 307 & -1035 \\
15 & 339 & -1021 \\
20 & 365 & -1008 \\
25 & 398 & -998 \\
Mild steel & -- & -630 \\
\hline
\end{tabular}

The surface morphology of $\mathrm{Zn}-\mathrm{Ni}$ alloy deposits containing different percentage of nickel were examined under scanning electron microscope. The morphology of the alloy deposits is shown in the Fig. 7.
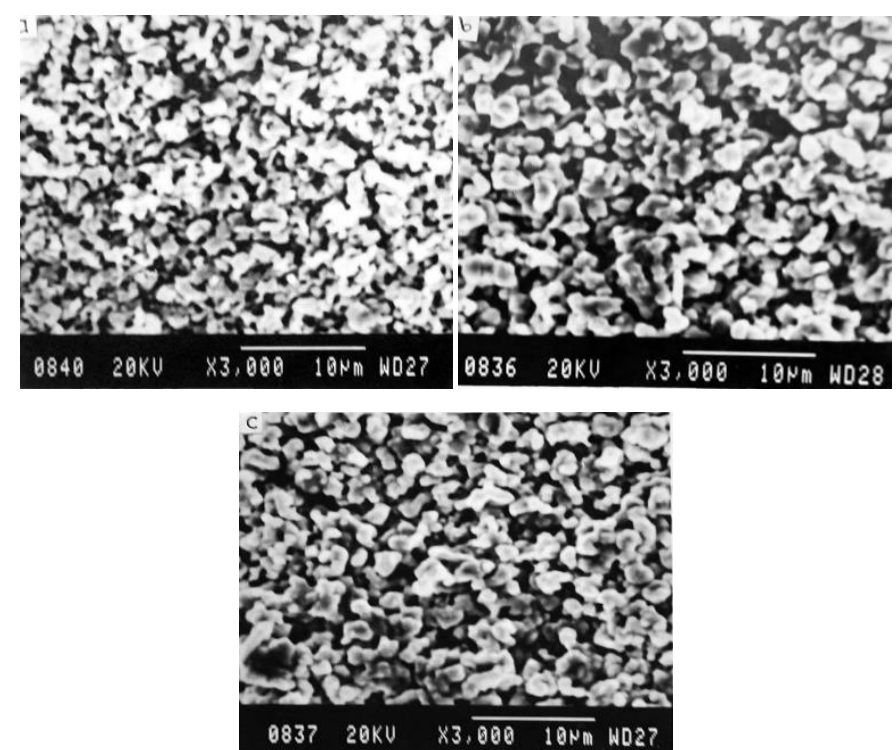

Fig. 7 Scanning electron microscopy of $\mathrm{Zn}-\mathrm{Ni}$ alloy deposits containing TEA and MPY (X3500). a) $10 \% \mathrm{Ni}$; b) $15 \% \mathrm{Ni}$; c) $20 \% \mathrm{Ni}$

\section{Conclusion}

Zn-Ni alloy containing $10-15 \% \mathrm{Ni}$, electrodeposited from an alkaline sulphate bath containing TEA and MPY is of regular type of co-deposition. The potential of $\mathrm{Zn}$-Ni alloy deposition lies in between those of individuals metals. The nickel content in the alloy deposit decreased with current density and increased with elevation in bath temperature, stirring of the bath solution and with thickness of the alloy deposit. Hardness of the alloy deposit was found to depend on nickel content of the alloy deposit. Fine grained deposits were observed morphologically.

\section{Acknowledgement}

The author, V. Narasimhamurthy thank the Chairman, Department of Metallurgy, Indian Institute of Science, Bangalore for SEM data and grateful to CSIR, New Delhi for the financial assistance.

\section{References}

[1] Ramesh S. Bhat, Vinayak B. Shet, Development and characterization of $\mathrm{Zn}-\mathrm{Ni}$ $\mathrm{Zn}-\mathrm{Co}$ and Zn-Ni-Co coatings, Surf. Eng. 6(4) (2020) 429-437.

[2] N. Lotfi, M. Aliofkhazraei, H. Rahmani, G. Barati Darband, Zinc-nickel alloy electrodeposition: characterization, properties, multilayer's and composites, Prot. Metals Phy. Chem. Surf. 54 (2018) 1102-1140.

[3] S. Rajendran, S. Bharathi, T. Vasudevan, Electrodeposition of zinc-nickel alloy from a cyanide-free alkaline plating bath, Trans. IMF 78(3) (2017) 129-133.

[4] S. Mohan, V. Ravindran, B. Subramanian, G. Saravanan, Electrodeposition of zinc-nickel alloy by pulse plating using non-cyanide bath, Trans. IMF 87(2) (2013) 85-89. 
[5] Satoru Ando, Electrodeposition behavior of $\mathrm{Zn}$-Ni alloys produced from sulfate solutions at high current densities, Mat. Trans. 57(11) (2016) 1908-1914.

[6] Zhongbao Feng, Qingyang Li, Jinqiu Zhang, Peixia Yang, Maozhong Anz, Electrochemical behaviors and properties of $\mathrm{Zn}-\mathrm{Ni}$ alloys obtained from alkaline non-cyanide bath using 5, 5'-dimethylhydantoin as complexing agent, J. Elect. Soc. 162(9) (2015) 412-422.

[7] Roventi, Electrodeposition of nickel-zinc alloy from a sulfamate bath, Advan. Mats. 4 (2015) 21-26.

[8] R. Katırcl, Effects of ZnO and $\mathrm{NaOH}$ in Zn-Ni bath, Surf. Eng. 31 (2015) 11-16

[9] K.O. Nayana, T.V. Venkatesha, Effect of ethyl vanillin on $\mathrm{Zn}-\mathrm{Ni}$ alloy electrodeposition and its properties, Bull. Mater. Sci. 37(5) (2014) 1137-1146.

[10] S.H. Mosavat, M.E. Bahrololoom, M.H. Shariat, Electrodeposition of nanocrystalline $\mathrm{Zn}-\mathrm{Ni}$ alloy from alkaline glycinate bath containing saccharin as additive, App. Surf. Sci. 257(20) (2011) 8311-8316.
[11] S. Yogesha, A.C. Hegde, Optimization of bright zinc-nickel alloy bath for better corrosion resistance, Trans. Inst. Met. 63 (2010) 841-846.

[12] L.S. Tsybulskaya, T.V. Gaevskaya, O.G. Purovskaya, Electrochemical deposition of zinc-nickel alloy coatings in a polyligand alkaline bath, Surf. Coat. Tech. 203 (2008) 234-239.

[13] M.G. Hosseini, H. Ashassi-Sorkhabi, H.A.Y. Ghiasvand, Study of corrosion performance of electrodeposited nanocrystalline $\mathrm{Zn}-\mathrm{Ni}$ alloy coatings, Surf Coat. Tech. 59 (2012) 81-87.

[14] S. Shanmugasigamani, M. Pushpavanam, Nanocrystalline zinc-nickel alloy deposition using pulse electrodeposition (PED) technique, Trans. IMF 86(2) (2008) 122-128.

[15] V. Ravindran, V.S. Muralidharan, Zinc-nickel alloy electrodeposition - influence of triethanolamine, Port. Elect. Acta. 25 (2007) 391-399.

[16] M.M. Abou-Krisha, F.H. Assaf, A.A. Toghan, Electrodeposition of Zn-Ni alloy from an acid sulfate bath, J. Sol. Stat. Elect. 11 (2007) 244-252. 